Article

\title{
Green Fabrication of Supported Platinum Nanoparticles by Supercritical $\mathrm{CO}_{2}$ Deposition
}

\author{
Ying-Liang Chen ${ }^{1} \mathbb{D}$, Cheng-Hsien Tsai ${ }^{2}$, Mei-Yin Chen ${ }^{3}$ and Yi-Chieh Lai ${ }^{4, *}$ \\ 1 Department of Environmental Engineering, National Cheng Kung University, Tainan 70101, Taiwan; \\ roy.yl.chen@gmail.com \\ 2 Department of Chemical and Materials Engineering, National Kaohsiung University of Science and \\ Technology, Kaohsiung 80778, Taiwan; chtsai@nkust.edu.tw \\ 3 Department of Chemistry, Chung Yuan Christian University, Chung-Li 32023, Taiwan; h577577@gmail.com \\ 4 Department of Safety, Health and Environmental Engineering, National Kaohsiung University of Science \\ and Technology, Kaohsiung 82445, Taiwan \\ * Correspondence: yclai@nkust.edu.tw; Tel.: +886-7-601-1000 (ext.32321)
}

Received: 30 November 2018; Accepted: 16 December 2018; Published: 18 December 2018

\begin{abstract}
Pt nanoparticles were successfully deposited on uncatalyzed carbon paper by the supercritical $\mathrm{CO}_{2}$ deposition (SCD) method using platinum (II) acetylacetonate as a precursor followed by thermal conversion. A full $2^{4}$ factorial design (four factors, each with two levels) was used to investigate the main effect of four factors (deposition temperature, deposition time, reduction temperature, and reduction time) and the interaction effects between them. The morphological structures and surface properties of the $\mathrm{Pt} /$ carbon paper composite were analyzed by $\mathrm{X}$-ray diffraction (XRD), scanning electron microscope (SEM)/energy-dispersive X-ray spectroscopy analyzer (EDS), and high-resolution transmission electron microscopy (HR-TEM). The results of the $2^{4}$ factorial design showed that Pt loading on the substrate correlated significantly with deposition time, while Pt aggregation slightly increased with the thermal reduction temperature. Data obtained from both XRD and HR-TEM were in good agreement and showed that Pt nanoparticles were homogeneously dispersed on the substrate with diameters of $7.2-8.7 \mathrm{~nm}$.
\end{abstract}

Keywords: Supercritical deposition; platinum; carbon dioxide; factorial design

\section{Introduction}

Supported noble-metal nanoparticles have recently been attracting attention in the field of microelectronics, optics, and catalytic applications due to their high activity and stability [1-3]. $\mathrm{Pt}$ nanoparticles are the most effective catalyst known for oxygen reduction, which is widely used for fuel cells [4,5]. Since fuel cells play a significant role in the generation of power, much attention has been given to the preparation of high-performance Pt-based nanoparticles for low temperature fuel cells [4-6]. These catalysts rely on various conventional techniques such as wet impregnation, spraying, sol-gel, chemical vapor deposition and electro-deposition [7,8]. Among these techniques, several challenges remain, including particle dimensions (size and distribution) and metal loading. Although the precise shapes and sizes of Pt nanoparticles can be fabricated by the modified version of polyol methods $[9,10]$, the use of toxic and hazardous reagents and solvents in the fabrication are considered an important environmental problem.

Interest in supercritical fluids and their potential use for metal nanoparticle preparations has significantly increased over the past decade. Supercritical $\mathrm{CO}_{2}\left(\mathrm{scCO}_{2}\right)$ is considered a green solvent for nanoparticle preparations following the deposition process because of its environmentally benign, non-toxic, non-polluting, and recoverable characteristics [11-13]. For Pt nanoparticles prepared by 
supercritical $\mathrm{CO}_{2}$ deposition (SCD), the appropriate Pt loading and catalyst structures are determined by the following parameters: types of substrate and precursor; deposition pressure; temperature and time; and, conversion method [3]. However, little information is available on the main and interaction effects of the SCD factors on particle characteristics (i.e., loading, size, and microstructures).

The purpose of this study was to determine the effects of the SCD conditions on the supported Pt characteristics. A full $2^{4}$ factorial design was used to evaluate the main effects as well as the interaction effects of the parameters during SCD with a $95 \%$ confidence limit. The morphological structures and surface properties of the $\mathrm{Pt}$ /carbon paper composite were analyzed by $\mathrm{X}$-ray diffraction (XRD), scanning electron microscope (SEM)/energy-dispersive X-ray spectroscopy analyzer (EDS), and high-resolution transmission electron microscopy (HR-TEM).

\section{Materials and Methods}

\subsection{Preparation of Pt Nanoparticles via Supercritical $\mathrm{CO}_{2}$ Deposition (SCD)}

The SCD experiment was performed in a high-pressure reaction chamber. A schematic view of the experimental setup is provided in Figure 1. The deposition apparatus consisted of a $100 \mathrm{~mL}$ stainless steel reaction chamber (SS-316, Amar Equipment, Ltd., Mumbai, India) equipped with a magnetic stirring bar, high-pressure pump, heating unit, pressure gauge, and inlet and outlet valves. The supercritical fluid used in this study was $\mathrm{CO}_{2}$ gas (purity $>99.99 \%$; Jing De Gases, Ltd., Kaohsiung, Taiwan), and a high-pressure pump (Model PM-10000B, Taiwan Supercritical Technology, Ltd., Changhua County, Taiwan) was used to pressurize the $\mathrm{CO}_{2}$ to the desired level. The high-pressure reaction chamber was then sealed with a stainless-steel clamp (Amar Equipment, Ltd., Mumbai, India) then heated to the desired temperature by a circulating heater/cooler (Amar Equipment, Ltd., Mumbai, India).

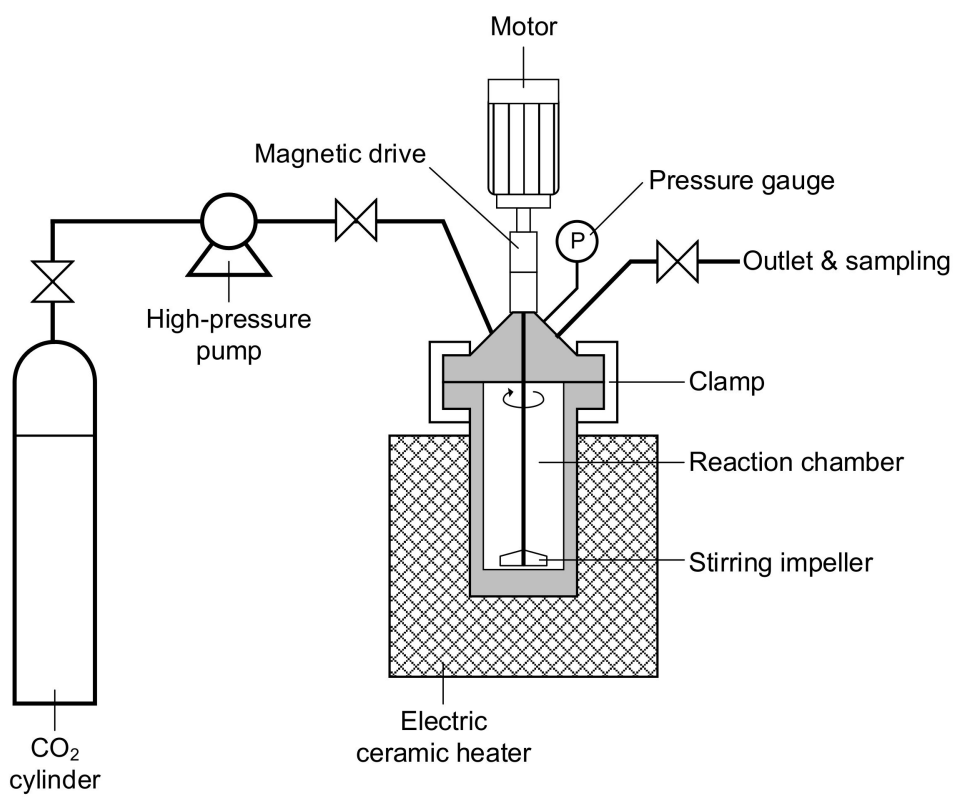

Figure 1. Schematic of the experimental setup.

The SCD process involved three main steps: (1) dissolution of a metallic precursor in $\mathrm{scCO}_{2}$ under a given condition; (2) molecular adsorption of the precursor on the support; and, (3) decomposition of the precursor to its metal form. In general, a metallic precursor can be converted to its metal form using different methods, including: (1) chemical reduction in $\mathrm{scCO}_{2}$ with a reducing agent (hydrogen); (2) thermal reduction in $\mathrm{scCO}_{2}$; (3) thermal reduction in an inert atmosphere; or, (4) chemical reduction with hydrogen at ambient pressure [1-3]. In this study, the precursor was reduced thermally in $\mathrm{scCO}_{2}$, as shown in Figure 2. 
For each SCD experiment, a known amount of platinum (II) acetylacetonate (Pt(II)(acac) ; 98\%) (Acros Organics, Fukuoka, Japan) precursor was placed into the stainless-steel reaction chamber, together with the activated carbon paper (without catalyst) (CeTech ${ }^{\mathrm{TM}}$, Taichung, Taiwan), for a projected active area of $5 \mathrm{~cm}^{2}$. The amount of $\mathrm{Pt}(\mathrm{II})(\mathrm{acac})_{2}$, calculated from the solubility in $\mathrm{scCO}_{2}$, was 10 times the saturating amount at the supercritical condition and, therefore, $\mathrm{Pt}(\mathrm{II})(\mathrm{acac})_{2}$ was fully soluble in $\mathrm{scCO}_{2}$ [14]. A piece of carbon paper (CeTech ${ }^{\mathrm{TM}}$, Taichung, Taiwan), $\mathrm{Pt}(\mathrm{II})(\mathrm{acac})_{2}$, and methanol (Acros Organics, Fukuoka, Japan) were placed in a high-pressure vessel (Amar Equipment, Ltd., Mumbai, India), which was slowly pressurized with $\mathrm{CO}_{2}(99.998 \%)$ at the given pressure $(10.3 \mathrm{MPa})$ and heated to the selected temperature for durations varying from 2 to $6 \mathrm{~h}$. Note that methanol was used as a co-solvent to enhance the solubility of the precursor in the $\mathrm{scCO}_{2}[3,15]$. The impregnated precursor was then reduced thermally at 200 and $250^{\circ} \mathrm{C}$ for $2-4 \mathrm{~h}$ under the supercritical environment. Once the reduction process was finished, the pressure was slowly released and the chamber cooled to room temperature. The Pt/carbon paper composite was then removed from the chamber and stored for further analysis.

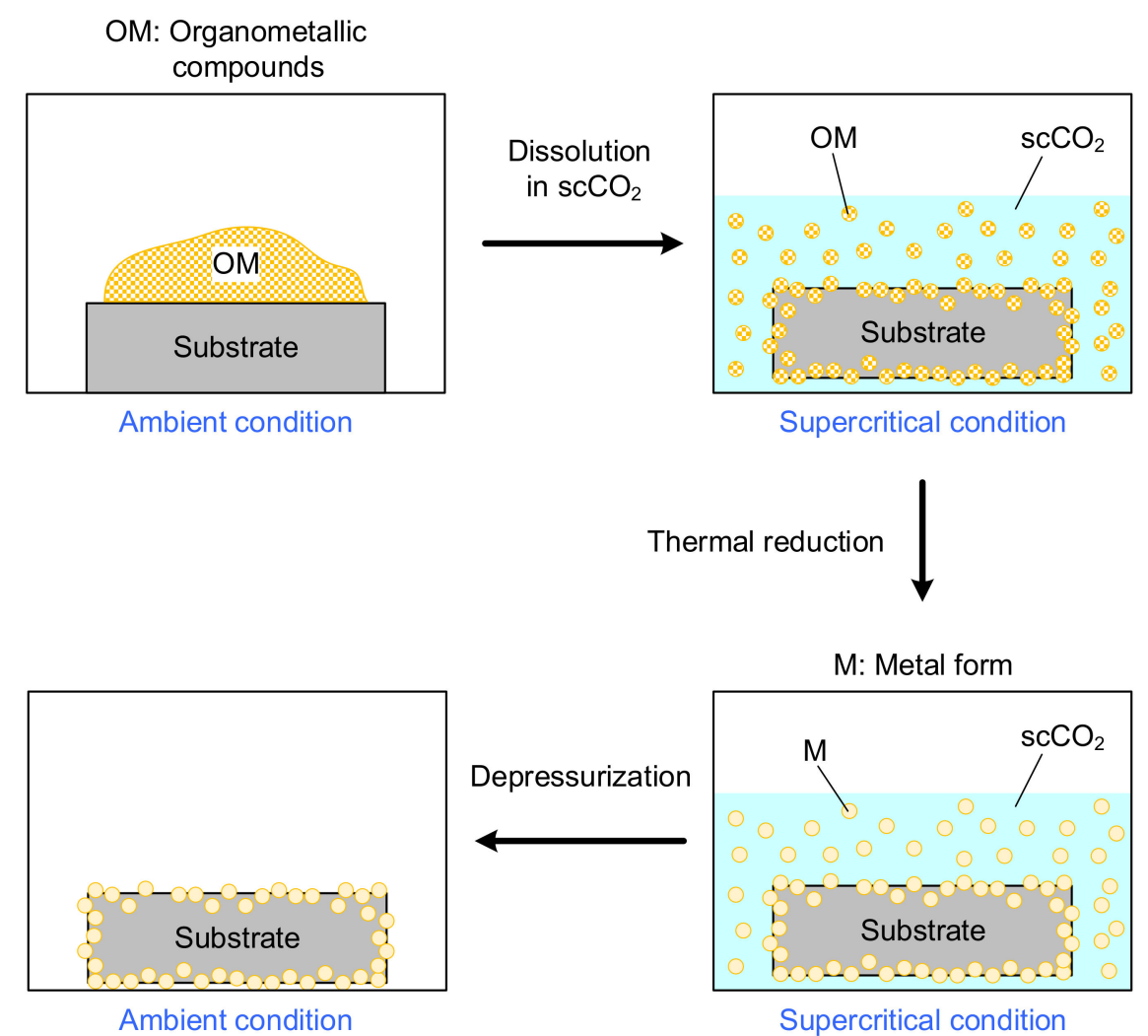

Figure 2. Schematic representation of the supercritical $\mathrm{CO}_{2}$ deposition (SCD).

\subsection{Full $2^{4}$ Factorial Design}

In order to gain more insight into the significance of the factors and their interaction on the $\mathrm{Pt}$ loading via $\mathrm{SCD}$, experiments were designed. In general, a $2^{\mathrm{n}}$ factorial design is the most common type of factorial design as it applies two levels and thereby reduces the number of experimental conditions $[16,17]$. In this manner, the reliability and efficiency of the obtained data can be improved through factorial design experiments.

In this study, a full $2^{4}$ factorial design (four factors, each with two levels) with a total of 16 experiments was used to investigate the main effect of four factors (deposition temperature and time, as well as reduction temperature and time) and the interaction effects between them. The high $(+1)$ and low $(-1)$ levels of the factors were selected based on previous experiments and the scientific literature $[2,3,13]$. The experiments were consistent with theories of factorial design, whereby all levels 
of each factor are combined with those of every other factor. Table 1 shows the factors and levels investigated in the factorial design. The full $2^{4}$ factorial design matrix and experimental responses (i.e., Pt loading) are presented in Table 2. The results of the $2^{4}$ factorial design were analyzed by analysis of variance (ANOVA, Minitab 18 statistical software (Minitab, Inc., State College, PA, USA)) and differences were considered as significant based on the $\mathrm{P}$ value with $>5 \%$ confidence level.

Table 1. Summary of the factors and levels included in the full $2^{4}$ factorial design.

\begin{tabular}{ccc}
\hline Factors & \multicolumn{2}{c}{ Levels } \\
\hline & Low $(-1)$ & High $(+1)$ \\
Deposition Temperature (DT) & $80{ }^{\circ} \mathrm{C}$ & $150{ }^{\circ} \mathrm{C}$ \\
Deposition Time (DH) & $2 \mathrm{~h}$ & $6 \mathrm{~h}$ \\
Reduction Temperature (RT) & $200{ }^{\circ} \mathrm{C}$ & $250{ }^{\circ} \mathrm{C}$ \\
Reduction Time (RH) & $2 \mathrm{~h}$ & $4 \mathrm{~h}$ \\
\hline
\end{tabular}

Table 2. Full $2^{4}$ factorial design matrix and experimental responses.

\begin{tabular}{ccccccc}
\hline & & \multicolumn{5}{c}{ Factors } \\
\cline { 3 - 5 } Run & $\begin{array}{c}\text { Factor } \\
\text { Combination }\end{array}$ & $\begin{array}{c}\text { Deposition } \\
\text { Temperature } \\
\text { (A) }\end{array}$ & $\begin{array}{c}\text { Deposition } \\
\text { Time } \\
\text { (B) }\end{array}$ & $\begin{array}{c}\text { Reduction } \\
\text { Temperature } \\
\text { (C) }\end{array}$ & $\begin{array}{c}\text { Reduction } \\
\text { Time } \\
\text { (D) }\end{array}$ & $\begin{array}{c}\text { Pt Loading } \\
\left(\mathbf{m g} / \mathbf{c m}^{2}\right)\end{array}$ \\
\hline 1 & 1 & -1 & -1 & -1 & -1 & 0.122 \\
2 & $\mathrm{~A}$ & +1 & -1 & -1 & -1 & 0.147 \\
3 & $\mathrm{~B}$ & -1 & +1 & -1 & -1 & 0.183 \\
4 & $\mathrm{AB}$ & +1 & +1 & -1 & -1 & 0.253 \\
5 & $\mathrm{C}$ & -1 & -1 & +1 & -1 & 0.196 \\
6 & $\mathrm{AC}$ & +1 & -1 & +1 & -1 & 0.242 \\
7 & $\mathrm{BC}$ & -1 & +1 & +1 & -1 & 0.265 \\
8 & $\mathrm{ABC}$ & +1 & +1 & +1 & -1 & 0.248 \\
9 & $\mathrm{D}$ & -1 & -1 & -1 & +1 & 0.189 \\
10 & $\mathrm{AD}$ & +1 & -1 & -1 & +1 & 0.142 \\
11 & $\mathrm{BD}$ & -1 & +1 & -1 & +1 & 0.220 \\
12 & $\mathrm{ABD}$ & +1 & +1 & -1 & +1 & 0.242 \\
\hline
\end{tabular}

\subsection{Characterization}

The Pt loading of the Pt/carbon paper composite was determined by inductively coupled plasma mass spectrometry (ICP-MS) (7500a; Agilent, California, USA) after acid digestion. This was achieved by assuming that the entire $\mathrm{Pt}$ in the adsorbed precursor was reduced to elemental $\mathrm{Pt}$ without volatilization during thermal reduction. The morphology of the $\mathrm{Pt} /$ carbon paper samples was evaluated using an SEM (JSM-7600F; JEOL Ltd., Tokyo, Japan) with the EDS (JEOL Ltd., Tokyo, Japan). The Pt/carbon paper samples were also examined using a HR-TEM (CM-200; Philips, Amsterdam, Netherlands) to determine their sizes, morphologies, and microstructures. For SEM analysis, the $\mathrm{Pt} /$ carbon paper composite was fixed on a piece of double-sided adhesive copper tape. For HR-TEM analysis, the Pt nanoparticles were dispersed in methanol and then placed on a copper grid. The crystal structure of the as-prepared Pt nanoparticles was determined using the XRD (X'Pert PRO MPD; Philips, Amsterdam, Netherlands) with CuKa radiation that scanned from 20 to $90{ }^{\circ} \mathrm{C}(2 \theta)$.

\section{Results and Discussion}

\subsection{Analysis of $2^{4}$ Factorial Design}

As presented in Table 2, the $\mathrm{Pt}$ loading on the $\mathrm{Pt} /$ carbon paper composite ranged from 0.122 to $0.265 \mathrm{mg} / \mathrm{cm}^{2}$, with the maximum amount of Pt loading performed in $\mathrm{scCO}_{2}$ at $80^{\circ} \mathrm{C}$ and $10.3 \mathrm{MPa}$ for $6 \mathrm{~h}$ then reduced thermally at $250^{\circ} \mathrm{C}$ for $2 \mathrm{~h}$. The main and interaction effects of the $2^{4}$ factorial design were determined using the General Linear Model of Minitab 18 statistical software. The ANOVA 
results for the factorial model are presented in Table 3. The p-value is defined as the smallest level of significance that results in the rejection of the null hypothesis, and is a useful tool in statistical analysis to indicate whether the result of the statistical hypothesis test is significant or not [16]. In general, a smaller p-value implies stronger evidence against the null hypothesis $[17,18]$. It was found that the p-values for the deposition time (DH) and reduction temperature (RT) factors were lower than 0.05 (95\% confidence interval) for the response "Pt loading", hence, these two factors had statistically significant effects $(\mathrm{p}<0.05)$ on the response. As for the $\mathrm{p}$-values of the two-factor interactions, all values were higher than 0.05 , indicating that all interactions were not significant. In addition, an increased sum of squares (SS) value indicates the significance of the corresponding factor [19].

Table 3. Results of the analysis of variance (ANOVA) for Pt loading on the Pt/carbon paper composite prepared by the SCD process.

\begin{tabular}{cccccc}
\hline Source & $\begin{array}{c}\text { Degree of } \\
\text { Freedom (DF) }\end{array}$ & $\begin{array}{c}\text { Adjust Sum of } \\
\text { Squares (SS) }\end{array}$ & $\begin{array}{c}\text { Adjust Mean } \\
\text { Squares (MS) }\end{array}$ & F-Value & P-Value \\
\hline DT & 1 & 0.00424 & 0.00424 & 2.53 & 0.173 \\
DH & 1 & 0.020606 & 0.020606 & 12.29 & 0.017 \\
RT & 1 & 0.020696 & 0.020696 & 12.35 & 0.017 \\
RH & 1 & 0.004234 & 0.004234 & 2.53 & 0.173 \\
DT*DH & 1 & 0.000752 & 0.000752 & 0.45 & 0.533 \\
DT*RT & 1 & 0.000931 & 0.000931 & 0.56 & 0.490 \\
$\mathrm{DT}^{*} \mathrm{RH}$ & 1 & 0.000011 & 0.000011 & 0.01 & 0.939 \\
$\mathrm{DH}^{*} \mathrm{RT}$ & 1 & 0.000032 & 0.000032 & 0.02 & 0.896 \\
$\mathrm{DH}{ }^{*} \mathrm{RH}$ & 1 & 0.000486 & 0.000486 & 0.29 & 0.613 \\
$\mathrm{RT}^{*} \mathrm{RH}$ & 1 & 0.000446 & 0.000446 & 0.27 & 0.628 \\
Error & 5 & 0.008381 & 0.001676 & & \\
Total & 15 & 0.060814 & & & \\
\hline
\end{tabular}

The validity of the model was found using a normal probability plot of the residuals (Figure 3a) and the plot of residual versus the fit of the residuals (Figure $3 b$ ). The normal plot of the residuals was used to verify the normality of the treatment data. The absence of a straight line in Figure $3 \mathrm{a}$ resulted in a normal distribution of residual values. All points were found to fall in the range of +2 to -2 , except for one point (run number 16), as seen in Figure 3b. Since no pattern was found in the plot, the constant variance assumption in the model was satisfied. Accordingly, the assumptions for both normality and constant variance of the model were met.

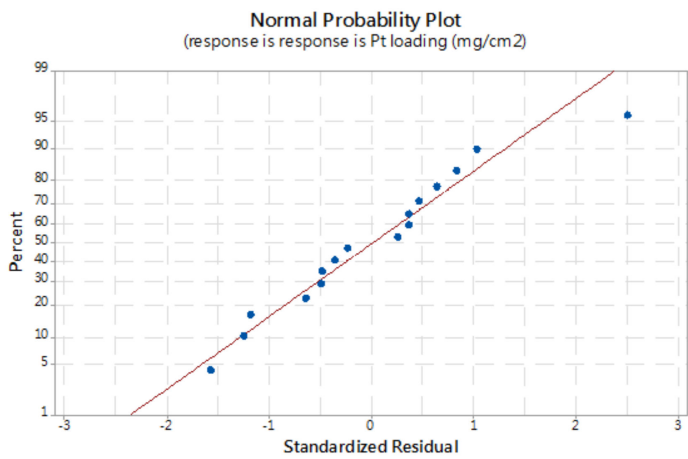

(a)

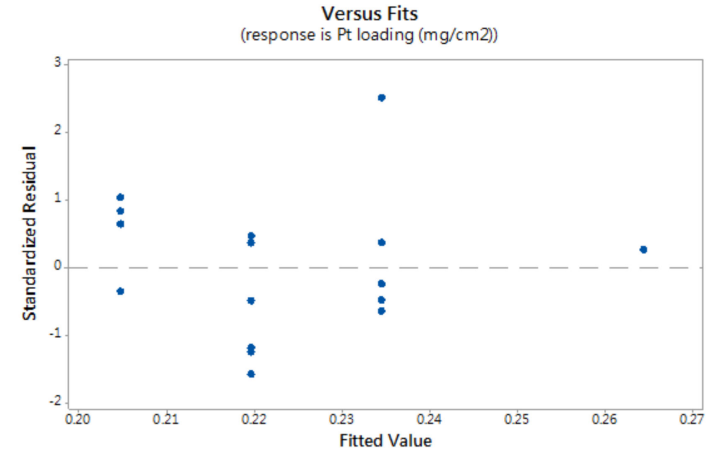

(b)

Figure 3. Residual plots in the regression analysis: (a) normal probability plot and (b) residuals versus fit of residuals. 


\subsection{Main and Interaction Effects}

The main effects plot, as seen in Figure 4a, reveals variations between the high and low values of each factor. When the slope is positive, the $\mathrm{Pt}$ loading is increasing by a corresponding factor. In this study, the higher slope values of $\mathrm{DH}$ and $\mathrm{RT}$ indicate that their effects were the most significant. Furthermore, the parallel lines in Figure $4 \mathrm{~b}$ indicate that there are no apparent interactions between factors. The normal probability plot (Figure 4c) was used to identify real effects [20]. Points (denoted as squares) located far away from the fitted line were considered significant. In this study, DH and RT, the main effects, were considered to have a significant effect on Pt loading, which is also confirmed in Figure 4a. A Pareto plot, as seen in Figure 4d, is typically applied to identify the significance of the factors and their interactions [19], which in this study was set at a $95 \%$ confidence interval. The values positioned to the right of the reference line (2.571) were considered significant factors. These results concur with the analysis of main effects, presented in Figure 4a. Accordingly, based on the factorial-design results shown in this study, $\mathrm{Pt}$ loading on the $\mathrm{Pt} /$ carbon paper composite fabricated by SCD can be enhanced by increasing the deposition time and reduction temperature.
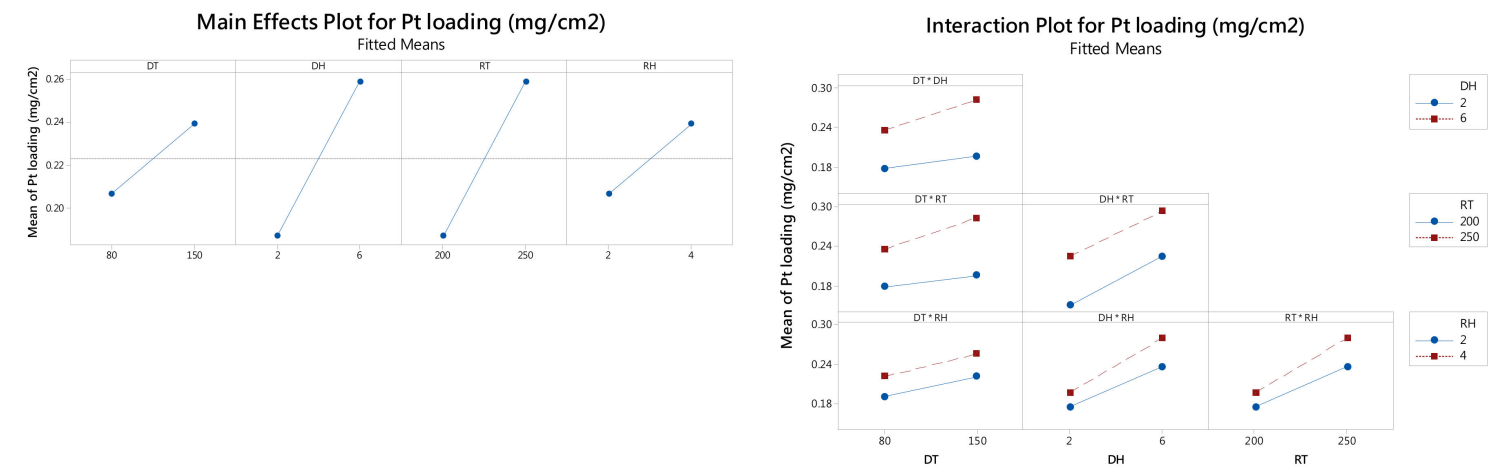

(a)

(b)
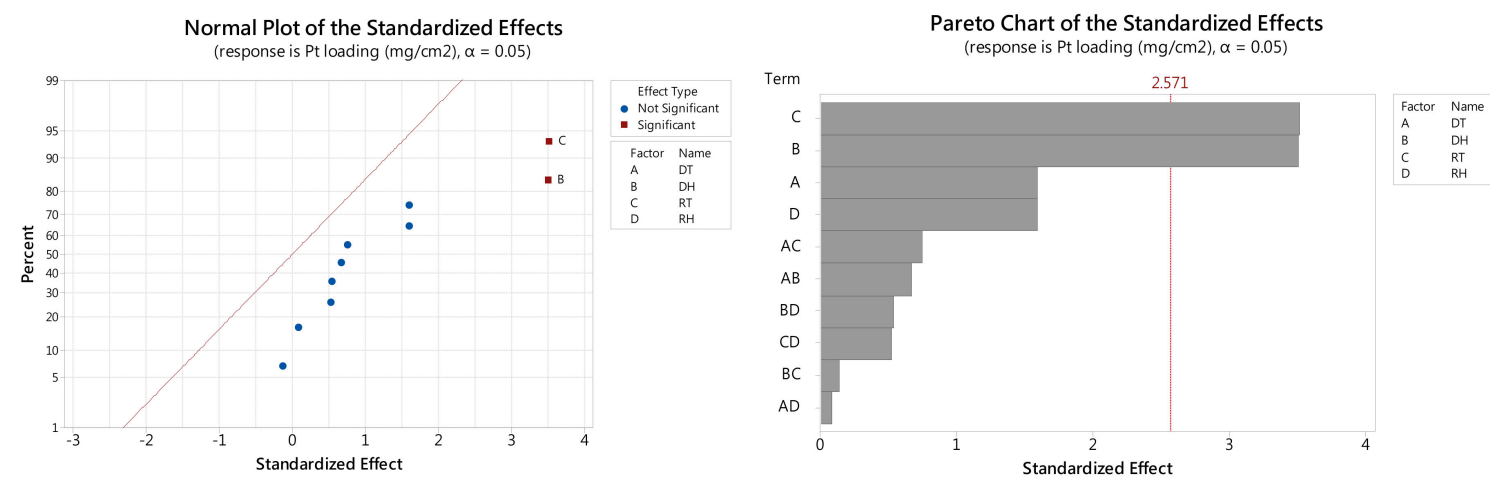

(c)

(d)

Figure 4. The factorial design plots of Pt loading on the Pt/carbon paper composite prepared by SCD: (a) main effects plot of response; (b) interaction plot of response; (c) normal plot of the standardized effect; and (d) Pareto chart of the standardized effect.

\subsection{Characterization of Pt/Carbon Paper Composites}

Figure 5 presents the XRD patterns for the fabricated $\mathrm{Pt} /$ carbon paper samples. Four crystalline

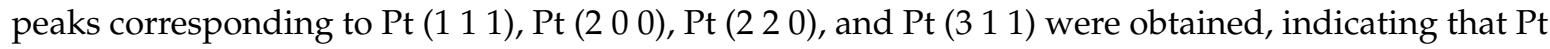
was in its metallic form in all samples. It is concluded that the $\mathrm{Pt}(\mathrm{II})(\mathrm{acac})_{2}$ can be converted to its metal form at $250{ }^{\circ} \mathrm{C}$. These findings are consistent with the results obtained from various supported Pt nanoparticles fabricated using SCD [2,21,22]. Moreover, the intensity of the Pt $\left(\begin{array}{lll}1 & 1 & 1\end{array}\right)$ peak was substantially greater than the others, revealing that the Pt crystal growth was predominately in the 
(1 11 1) direction. The mean size of the Pt (1 11 1) grains can be calculated using Scherrer's formula, as presented in our previous study [6]. The calculated Scherrer crystallite size for samples with deposition times of 2, 4, and $6 \mathrm{~h}$ were $7.5,7.9$, and $8.4 \mathrm{~nm}$, respectively, thereby demonstrating slight increases with increasing deposition time.

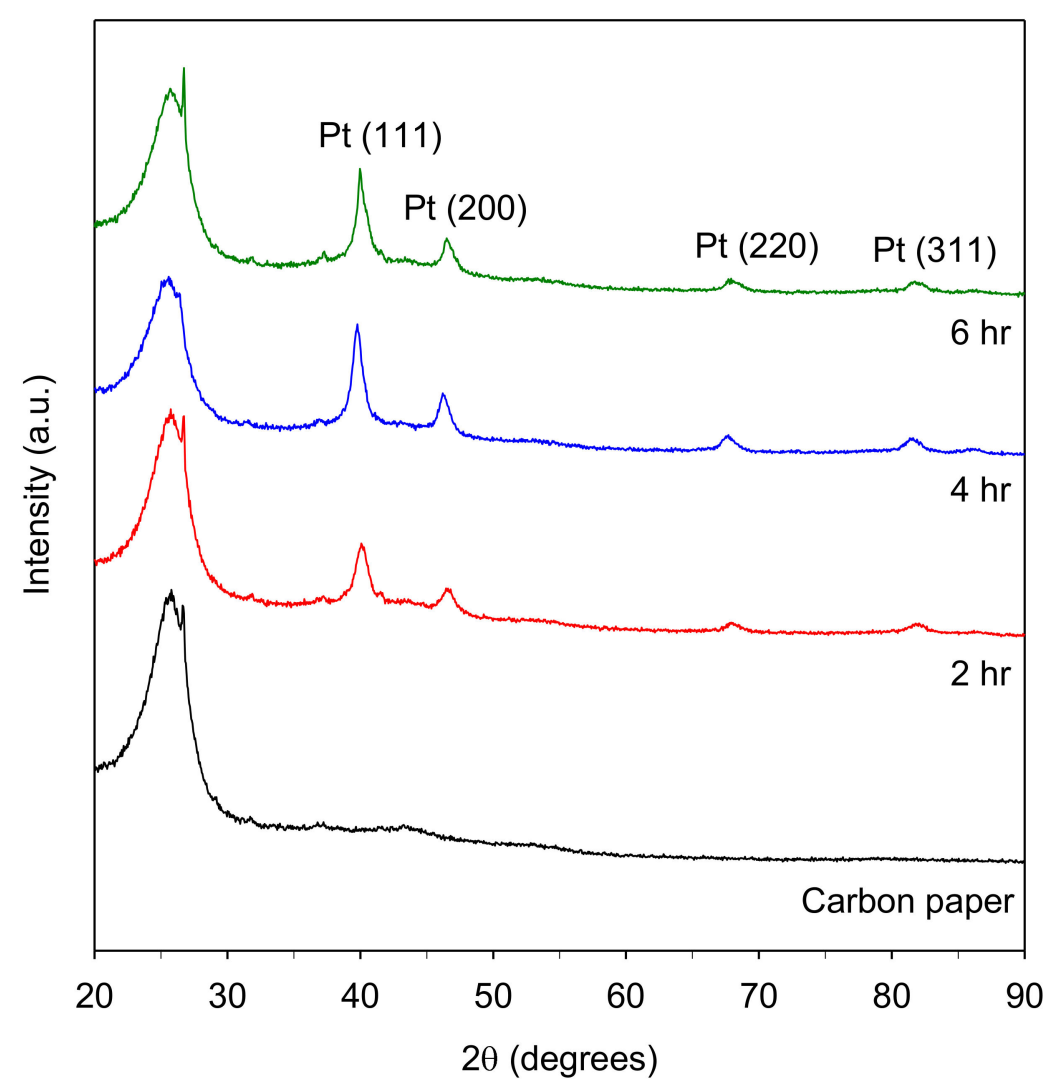

Figure 5. XRD patterns of Pt-deposited carbon paper fabricated by SCD at $80{ }^{\circ} \mathrm{C}$ and various time intervals by thermal reduction at $250{ }^{\circ} \mathrm{C}$ for $2 \mathrm{~h}$.

The HR-TEM images and Pt particle size distribution on the Pt/carbon paper samples fabricated with different deposition times are given in Figure 6. Particle size distributions were obtained based on 100 particles on each sample randomly selected from the HR-TEM images. The results showed that the Pt nanoparticles were dispersed homogenously on the surface of the carbon paper. The mean particle size for samples with deposition times of 2,4 , and $6 \mathrm{~h}$ were $7.2,8.4$, and $8.7 \mathrm{~nm}$, respectively, which concurs with the crystallite size obtained by XRD analysis $(7.5-8.4 \mathrm{~nm})$. Similarly, increasing the deposition time resulted in an increase in the $\mathrm{Pt}$ particle size of the $\mathrm{Pt} /$ carbon paper samples due to the aggregation of the Pt particles during SCD [6,10,21,22].

Based on the analysis of variance and the factorial design of experiments, the optimal parameters for the Pt/carbon paper (with Pt loading of $0.265 \mathrm{mg} / \mathrm{cm}^{2}$ ) fabricated using SCD are listed as follows: deposition temperature $=80^{\circ} \mathrm{C}$; deposition time $=6 \mathrm{~h}$; reduction temperature $=250{ }^{\circ} \mathrm{C}$; and reduction time $=2 \mathrm{~h}$. Figure 7 displays the top view SEM and EDX images of the above-mentioned sample. Figure 7a,b clearly indicate that the Pt particles were homogeneously dispersed on the carbon particles as well as inside the porous structure of the carbon paper. Analysis using EDX spectrometers (Figure $7 \mathrm{c}, \mathrm{d}$ ) confirmed the presence of the elemental $\mathrm{Pt}$ signal of the $\mathrm{Pt} / \mathrm{carbon}$ paper samples, thereby confirming that Pt nanoparticles were successfully deposited via the SCD method. 
(a)

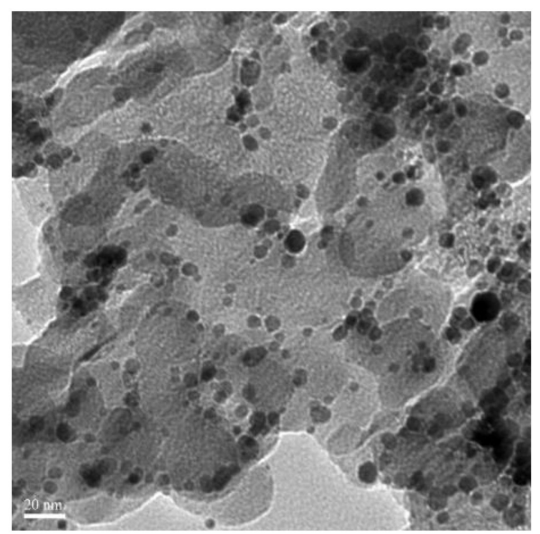

(b)

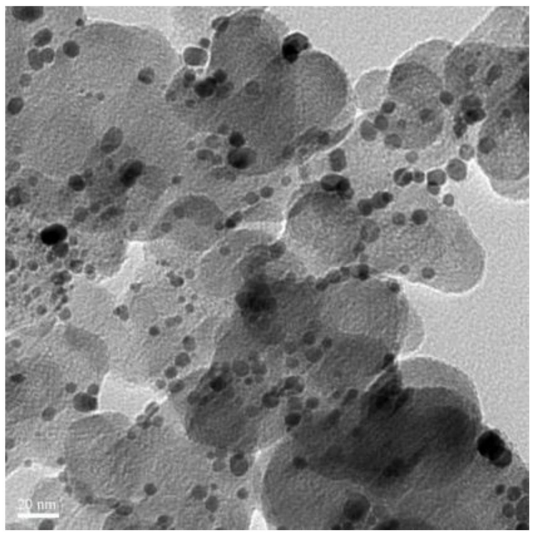

(c)

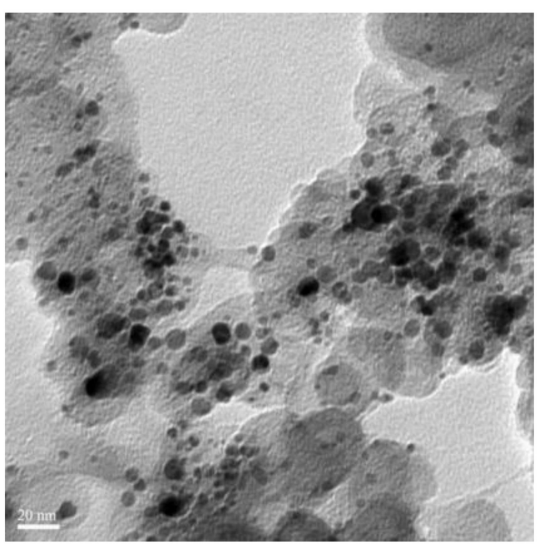

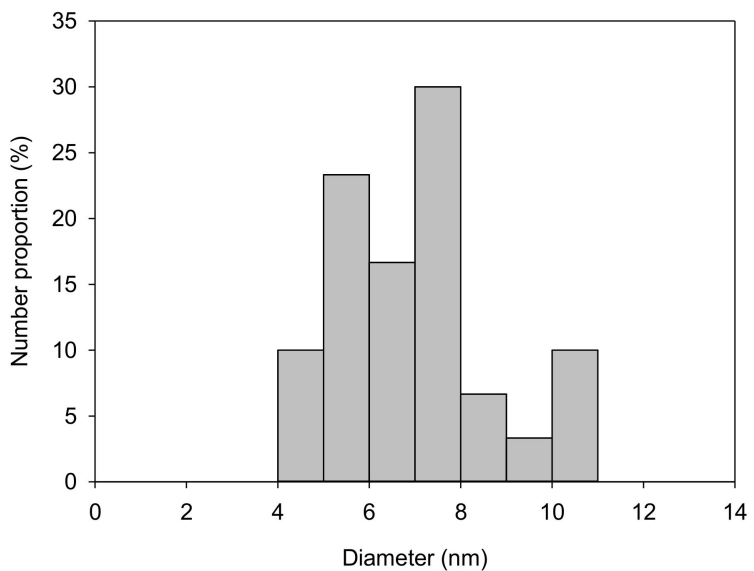
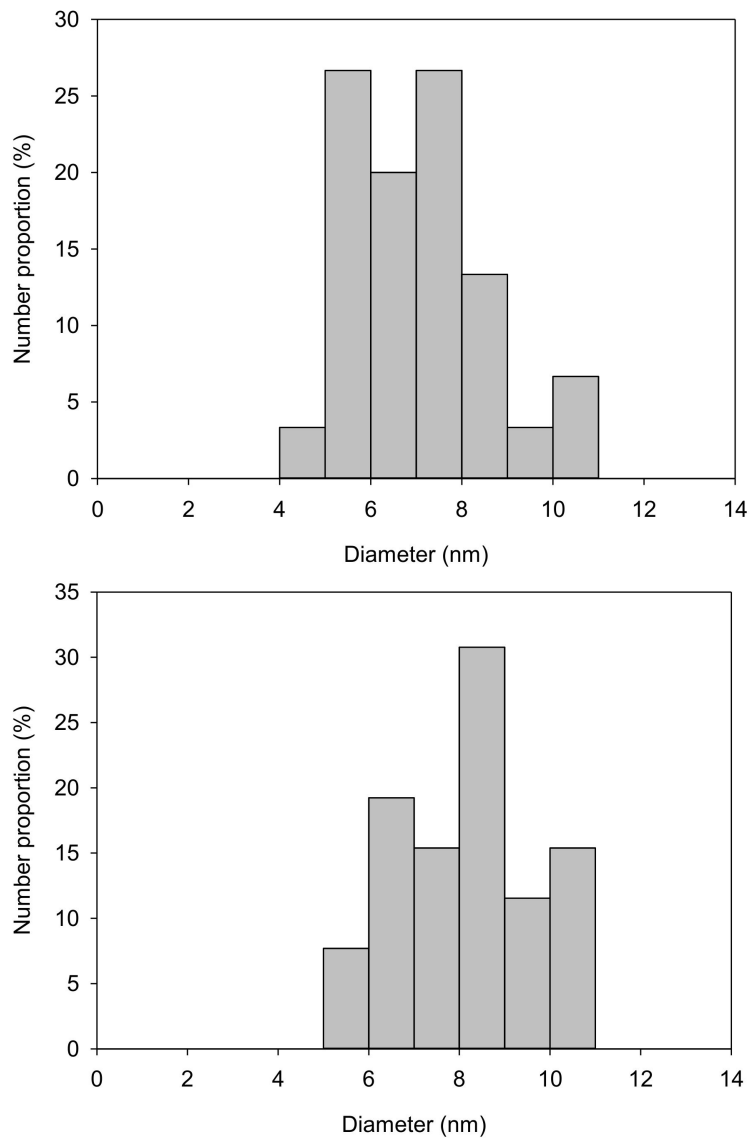

Figure 6. HR-TEM images and Pt particle-size distribution fabricated by SCD at $80^{\circ} \mathrm{C}$ for different time durations: (a) $2 \mathrm{~h}$; (b) $4 \mathrm{~h}$; and, (c) $6 \mathrm{~h}$. 


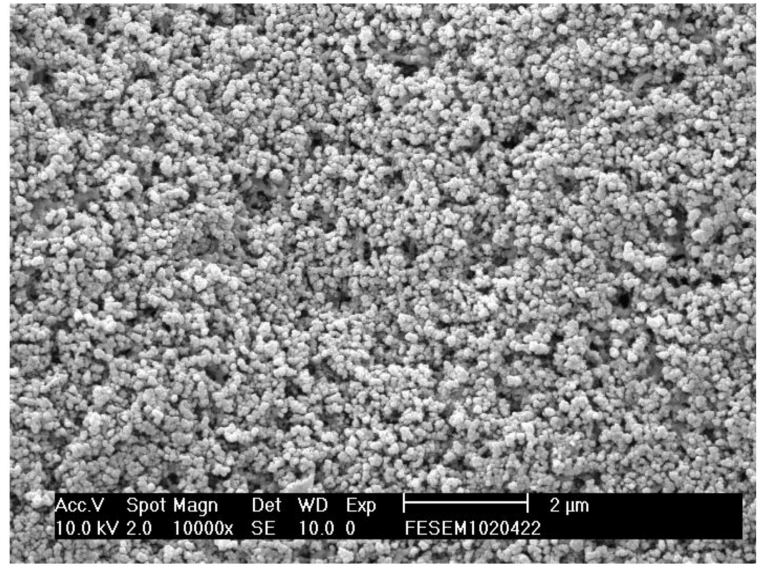

(a)

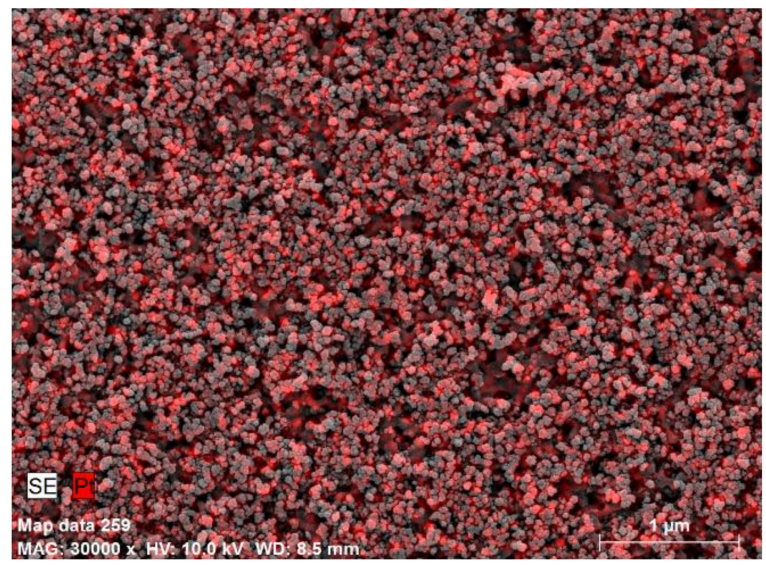

(c)

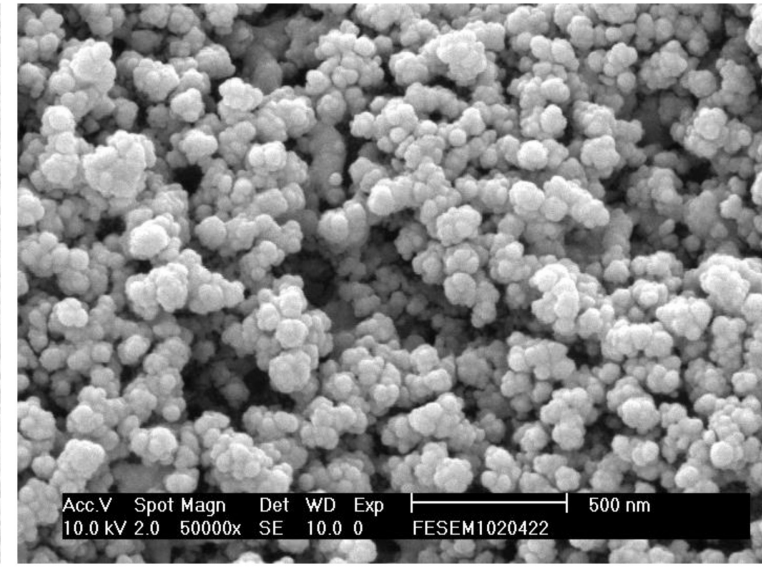

(b)

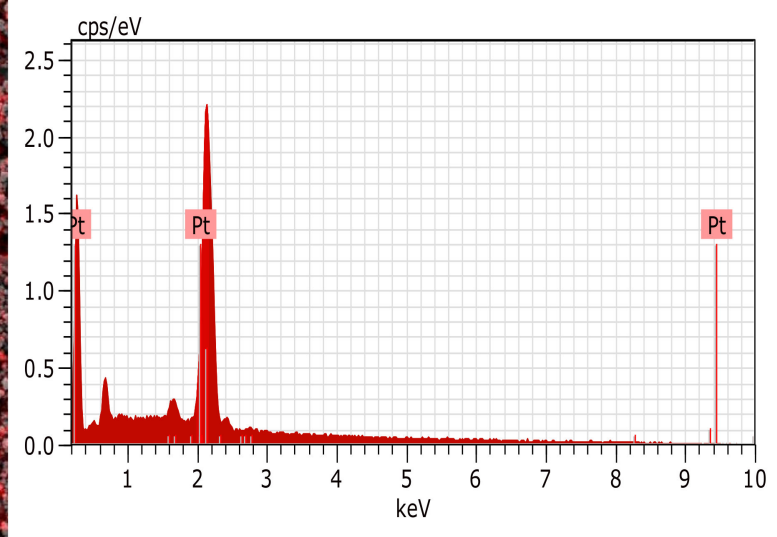

(d)

Figure 7. (a) SEM photograph $(\times 10000),($ b $)$ SEM photograph $(\times 50000)$, (c) EDX mapping image, and (d) EDX spectrum of supported Pt nanoparticles fabricated by SCD at $80^{\circ} \mathrm{C}$ and $6 \mathrm{~h}$.

\section{Conclusions}

Pt nanoparticles were successfully deposited on non-catalyzed carbon paper by the SCD method using platinum (II) acetylacetonate as a precursor. A $2^{4}$ factorial design was applied to investigate the influence of parameters (deposition temperature and time, as well as reduction temperature and time) on the $\mathrm{Pt}$ loading of the $\mathrm{Pt} /$ carbon paper composite. The results showed that $\mathrm{Pt}$ loading on the substrate correlates significantly with deposition time, while Pt aggregation increased with increases in the thermal reduction temperature. Data obtained from both XRD and HR-TEM were in good agreement and showed that $\mathrm{Pt}$ was homogeneously dispersed on the substrate with diameters in the range of 7.2-8.7 $\mathrm{nm}$. The optimal parameters for the $\mathrm{Pt} /$ carbon paper (with $\mathrm{Pt}$ loading of $0.265 \mathrm{mg} / \mathrm{cm}^{2}$ ) fabricated using SCD were found to be $80^{\circ} \mathrm{C}$ for $6 \mathrm{~h}$, followed by thermal reduction at $250^{\circ} \mathrm{C}$ for $2 \mathrm{~h}$, with the addition of methanol as a co-solvent. Overall, the properties of the supported metallic nanoparticles such as loading, size, distribution, and morphology depend closely on the conditions of the SCD method (type of substrate, precursor, temperature, time, conversion method, etc.). The results from this study could contribute to the development of commercial applications for SCD, however, further investigations of the obtained metallic nanoparticles properties (e.g., catalytic activity, and electrochemical performance) are needed.

Author Contributions: Conceptualization and methodology, Y.-C.L.; validation and analysis, Y.-L.C., C.-H.T., and M.-Y.C.; writing, original draft preparation, Y.-L.C., C.-H.T., and Y.-C.L.; writing, review and editing, Y.-L.C., C.-H.T., and Y.-C.L. 
Funding: This research was funded by the Ministry of Science and Technology, Taiwan (NSC 101-2221-E-033 -030).

Conflicts of Interest: The authors declare no conflict of interest.

\section{References}

1. Türk, M.; Erkey, C. Synthesis of supported nanoparticles in supercritical fluids by supercritical fluid reactive deposition: Current state, further perspectives and needs. J. Supercrit. Fluids 2018, 134, 176-183. [CrossRef]

2. Sánchez-Miguel, E.; Tenorio, M.J.; Morère, J.; Cabañas, A. Green preparation of PtRu and PtCu/SBA-15 catalysts using supercritical $\mathrm{CO}_{2}$. J. $\mathrm{CO}_{2}$ Util. 2017, 22, 382-391. [CrossRef]

3. Bozbag, S.E.; Erkey, C. Supercritical deposition: Current status and perspectives for the preparation of supported metal nanostructures. J. Supercrit. Fluids 2015, 96, 298-312. [CrossRef]

4. Huang, K.L.; Lai, Y.C.; Tsai, C.H. Effects of sputtering parameters on the performance of electrodes fabricated for proton exchange membrane fuel cells. J. Power Sources 2006, 156, 224-231. [CrossRef]

5. Sui, S.; Wang, X.; Zhou, X.; Su, Y.; Riffat, S.; Liu, C. A comprehensive review of Pt electr Catalysts for the oxygen reduction reaction: Nanostructure, activity, mechanism and carbon support in PEM fuel cells. J. Mater. Chem. A 2017, 5, 1808-1825. [CrossRef]

6. Lai, Y.C.; Huang, K.L.; Tsai, C.H.; Lee, W.J.; Chen, Y.L. Sputtered Pt loadings of membrane electrode assemblies in proton exchange membrane fuel cells. Int. J. Energy Res. 2012, 36, 918-927. [CrossRef]

7. Firtina, I.; Güner, S.; Albostan, A. Preparation and characterization of membrane electrode assembly (MEA) for PEMFC. Int. J. Energy Res. 2010, 35, 146-152. [CrossRef]

8. Yu, W.; Porosoff, M.D.; Chen, J.G. Review of Pt-based bimetallic catalysis: from model surfaces to supported catalysts. Chem. Rev. 2012, 112, 5780-5817. [CrossRef] [PubMed]

9. Sápi, A.; Varga, A.; Samu, G.F.; Dobó, D.G.; Juhász, K.L.; Takács, B.; Varga, E.; Kukovecz, Á.; Kónya, Z.; Janáky, C. Photoelectr chemistry by design: Tailoring the nanoscale structure of $\mathrm{Pt} / \mathrm{NiO}$ composites leads to enhanced photoelectr chemical hydrogen evolution performance. J. Phys. Chem. C 2017, 121, 12148-12158. [CrossRef] [PubMed]

10. Sápi, A.; Halasi, G.; Kiss, J.; Dobó, D.G.; Juhász, K.L.; Kolcsár, V.J.; Ferencz, Z.; Vári, G.; Matolin, V.; Erdőhelyi, A.; et al. In Situ DRIFTS and NAP-XPS Exploration of the Complexity of $\mathrm{CO}_{2}$ Hydrogenation over Size-Controlled Pt Nanoparticles Supported on Mesoporous NiO. J. Phys. Chem. C 2018, 122, 5553-5565. [CrossRef]

11. Saquing, C.D.; Kang, D.; Aindow, M.; Erkey, C. Investigation of the supercritical deposition of platinum nanoparticles into carbon aerogel. Microporous Mesoporous Mater. 2005, 80, 11-23. [CrossRef]

12. Aspromonte, S.; Sastre, A.; Boix, A.; Cero, M.J.C.; Alonso, E. Optimization and modelling of the supercritical $\mathrm{CO}_{2}$ deposition of $\mathrm{Co}_{\mathrm{x}} \mathrm{O}_{\mathrm{y}}$ nanoparticles in MCM41. J. Supercrit. Fluids 2016, 110, 47-55. [CrossRef]

13. Oztuna, F.E.S.; Barim, S.B.; Bozbag, S.E.; Yu, H.B.; Aindow, M.; Unal, U.; Erkey, C. Graphene aerogel supported pt electro Catalysts for oxygen reduction reaction by supercritical deposition. Electr Chim. Acta 2017, 250, 174-184. [CrossRef]

14. Türk, M.; Crone, M.; Upper, G. Effect of gas pressure on the phase behaviour of organometallic compounds. J. Supercrit. Fluids 2011, 58, 1-6. [CrossRef]

15. Chen, A.Z.; Wang, G.Y.; Wang, S.B.; Feng, J.G.; Liu, Y.G.; Kang, Y.Q. Preparation of poly-(methyl vinyl ether-co-maleic anhydride) nanoparticles by solution-enhanced dispersion by supercritical $\mathrm{CO}_{2}$. Materials 2012, 5, 1841-1852. [CrossRef]

16. Montgomery, D.C. Design and Analysis of Experiments, 3rd ed.; Wiley: New York, NY, USA, 1991.

17. Berger, P.D.; Maurer, R.E. Experimental Design, 1st ed.; Easter Press Pvt. Ltd: Bangalore, India, 2002.

18. Sterne, J.A.C.; Smith, G.D. Sifting the evidence-What's wrong with significance tests? Phys. Therapy 2001, 81, 1464-1469. [CrossRef] [PubMed]

19. Farooq, S.; Saeed, A.; Sharif, M.; Hussain, J.; Mabood, F.; Iftekhar, M. Pr Cess optimization studies of crystal violet dye adsorption onto novel, mixed metal $\mathrm{Ni}_{0.5} \mathrm{Co}_{0.5} \mathrm{Fe}_{2} \mathrm{O}_{4}$ ferrospinel nanoparticles using factorial design. J. Water Pr Cess Eng. 2017, 16, 132-141. [CrossRef]

20. Camacho, L.M.; Fox, J.A.; Ajedegba, J.O. Optimization of electrodialysis metathesis (EDM) desalination using factorial design methodology. Desalination 2017, 403, 136-143. [CrossRef] 
21. Bozbag, S.E.; Yasar, N.S.; Zhang, L.C.; Aindow, M.; Erkey, C. Absorption of Pt(cod)me 2 onto organic aerogels from supercritical solutions for the synthesis of supported platinum nanoparticles. J. Supercrit. Fluids 2011, 56, 105-113. [CrossRef]

22. Barım, Ş.B.; Bayrakçeken, A.; Bozbağ, S.E.; Zhang, L.; Kızılel, R.; Aindow, M.; Erkey, C. Control of average particle size of carbon aerogel supported platinum nanoparticles by supercritical deposition. Microporous Mesoporous Mater. 2017, 245, 94-103. [CrossRef]

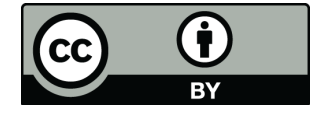

(C) 2018 by the authors. Licensee MDPI, Basel, Switzerland. This article is an open access article distributed under the terms and conditions of the Creative Commons Attribution (CC BY) license (http:/ / creativecommons.org/licenses/by/4.0/). 